\title{
Rapid tests for the toxicity evaluation of soil contaminated by lead- acid batteries manufacture
}

\author{
Tavares, C.B.B. ${ }^{1}$; Hoscha, L.C. ${ }^{1,2}$; Tavella, R.A. ${ }^{1,2}$; Fernandes, C.L.F. ${ }^{1,2}$; Fanton, T. ${ }^{3}$; Baisch, P.R.M. \\ Chaves, I.S. ${ }^{1} \&$ DA Silva JúnIOR, F.M.R ${ }^{1,2 *}$ \\ ${ }^{1}$ Instituto de Ciências Biológicas, Universidade Federal do Rio Grande. Rio Grande, Brasil. \\ ${ }^{2}$ Programa de Pós-Graduação em Ciências Da Saúde, Faculdade de Medicina, Universidade Federal do Rio Grande. \\ ${ }^{3}$ Escola de Engenharia, Universidade Federal do Rio Grande. \\ ${ }^{4}$ Instituto de Oceanografia, Universidade Federal do Rio Grande.
}

Received October 5, 2017; Accept March 12, 2018

\begin{abstract}
Lead-acid battery manipulation is one of the major sources of environmental contamination of lead in developing and underdeveloped countries. For the preliminary investigation of the soil ecotoxicological potential of a mechanical workshop with deposit of lead-acid battery tailings, the avoidance behavior response test with Eisenia andrei and the phytotoxicity test with Lactuca sativa were made. The quantification of cadmium, copper, lead, zinc, manganese, iron and arsenic, was also performed. The level of lead found in the test soil was 56 times higher than the permitted value in Brazilian legislation, but the soil only showed toxicity in the avoidance behavior response test with earthworms. None of the phytotoxicity tests showed toxicity to lettuce seeds in germination rate and seedling length. This preliminary study confirms the contamination of these sites by lead and indicates that this contamination can cause damages to the edaphic fauna, suggesting further studies in areas contaminated by tailings of lead-acid batteries.
\end{abstract}

Keywords: Eisenia andrei; Environmental contamination; Lactuca sativa; Lead.

\section{INTRODUCTION}

Although volcanic emissions and rock weathering are natural sources of lead, anthropic activities are undoubtedly the main current sources of this element (Azevedo \& Chasin, 2003; Rauch \& Pacyna, 2009). Automotive sources, industrial wastes, manufacture of materials made from metal alloys and lead-acid battery factories are the main anthropic sources reported for this metal (Irwin et al., 1997). Obsolete technologies, mainly in developing and underdeveloped countries, have contributed to local environmental contamination by lead (Mao et al., 2006).

The impact to human health from exposure to environments surrounding lead-acid battery factories is well elucidated in the literature (Van der Kuijp et al., 2013), as well as the evaluation of the exposure scenario (Chen et al., 2012; Liu et al., 2014) and quantification of soil chemical elements (Onianwa \& Fakayode, 2000) and in the air (Quiterio et al., 2006). On the other hand, the extent of effects on soil organisms from this exposure has been less investigated (Chao et al., 2016).

The toxic effects on soil organisms can be accessed through laboratory bioassays and conducted in two phases: a preliminary phase and a confirmatory phase. The tests chosen for the preliminary phase should be rapid, inexpensive and must provide evidence of more susceptible organisms and prevalent forms of exposure (Chen \& Liu, 2006; Pereira et al., 2013; Santos, Salles and Campolino, 2017; Wijayawardena et al., 2017; Omouri et al., 2018 . Among these possible bioassays are the avoidance behavior response test and the phytotoxicity test with lettuce seeds (Da Silva Júnior et al., 2014).

Previous studies have identified high concentrations of lead in soil (Fragomeni et al., 2010; Garcia et al., 2010) and

*Corresponding author: Flavio Manoel Rodrigues da Silva Júnior; e-mail: f.m.r.silvajunior@gmail.com 
atmospheric air (Vanz et al., 2003) in the city of Rio Grande, located in Rio Grande do Sul State, Brazil. Although Rio Grande has an important industrial complex associated with petroleum refining and harbor activities, the distribution of lead through the city seems not to be related to this industrial activities (Fragomeni et al., 2010; Vanz et al., 2003). Vanz et al. (2003) warn that part of the contribution of environmental lead is not of industrial origin, but possibly related to fishing activities, lead-based paint or other unidentified activities. In this article, we verified if the manufacture of lead-acid batteries can contribute to the increase of environmental lead and if the soil contaminated by this activity causes damage to exposed organisms.

\section{METHODS}

\section{Sampling}

Soil samples were collected from five different points in a site of a battery storage yard of a mechanical workshop, located in Rio Grande, Rio Grande do Sul State, Brazil. The control soil consisted of a soil collected within the campus of the Federal University of Rio Grande, previously used in other studies (Da Silva Júnior et al., 2014). In the laboratory, the collected soil samples were homogenized, sieved $(2 \mathrm{~mm})$ and conditioned in trays. The grain size was measured using the wet sieving technique (Robertson et al., 1984). The $\mathrm{pH}$ value of soil BSY was evaluated using $\mathrm{pH}$ meter in 20 grams of soil dissolved in $20 \mathrm{~mL}$ of distilled water. The total organic matter content $(\mathrm{OM})$ was estimated by ignition at $550^{\circ}$ for $4 \mathrm{~h}$. To evaluate the soil moisture, 10 grams of soil was placed in the oven at $105^{\circ} \mathrm{C}$ for two hours.

\section{Preparation of elutriate}

About $100 \mathrm{~g}$ of soil was weighed and added to $200 \mathrm{~mL}$ of distilled water. This solution was mixed and allowed to stir for 24 hours on the shaker table. After this period, the mixture was kept at rest and the supernatant (elutriate) was removed.

\section{Avoidance behavior test with Eisenia andrei}

On a rectangular plastic container were placed $350 \mathrm{~g}$ of test soil, and on the other side were placed $350 \mathrm{~g}$ of control soil. Between the two soils were placed 10 adult earthworms and the plastic container was covered with plastic film with holes and maintained at $20^{\circ} \mathrm{C}$ in a $12 \mathrm{~h} / 12 \mathrm{~h}$ photoperiod for 48 hours. After the 48 hours, a division was placed between the two soils and counted the number of earthworms in each soil. For the analysis of this test it was used the parameter mentioned by Loureiro et al. (2009) where soil habitat functionality is considered limiting if more than $80 \%$ of the organisms are found in the control soil. This test was performed according to ABNT NBR ISSO 17512-1:2011 (ABNT, 2011).

For this assay, the elutriate soils, prepared with dry weight soil, of the battery storage yard were diluted with distilled water in different concentrations $(0 \%, 1 \%, 3 \%, 10 \%, 30 \%$, $60 \%$ and $100 \%$ ) to evaluate a dose-response curve. The assay was carried out in Petri dishes containing filter paper, where 20 seeds of Lactuca sativa. Commercial seeds were placed on each plate (in triplicate) with $4 \mathrm{~mL}$ of the solution in the corresponding concentration. After 5 days at $20^{\circ} \mathrm{C}$ in the dark, the germination rate and seedling length were measured, according to ABNT, NBR 11: 269: 2014 (ABNT, 2014). The dry weight of the soil was obtained after drying the soil in an oven $105^{\circ} \mathrm{C}$ for two hours.

To evaluate the toxicity of the soil from the battery storage yard, test soils were mixed to control soil resulting in different concentrations $(0 \%, 1 \%, 3 \%, 10 \%, 30 \%, 60 \%$ and $100 \%)$. The following step of the evaluation was similar to the assessment of acute soil elutriate toxicity, and the substitution of $4 \mathrm{~mL}$ of the solution for distilled water was the only difference.

\section{Analysis of the elements ( $\mathrm{Cd}, \mathrm{Cu}, \mathrm{Pb}, \mathrm{Zn}, \mathrm{Mn}, \mathrm{Fe}$ and $\mathrm{As}$ )}

Copper and zinc were analyzed by flame atomic absorption spectrophotometry (AAS Perkin-Elmer 800), while electrochemical atomization mode with Zeeman correction was used in the analysis of chromium, nickel, lead, arsenic and cadmium in the soil. The maximum value of the relative standard deviation for the analysis of 3 replicates of an individual sample was less than $4 \%$.

\section{Statistical analysis}

Data were presented as mean \pm standard error of the mean for both avoidance behavior response test with Eisenia andrei and the toxicity assessment (for soil and the elutriate). The avoidance behavior response test was statistically compared using Fisher exact test, and both toxicity assessment was statistically compared using ANOVA and post-hoc Dunnet with $95 \%$ significance.

\section{RESULTS}

The granulometry and field capacity of the battery storage yard (BSY) and control soils are described in Table 1. The $\mathrm{pH}$ value of BSY soil was 9.73. The weight of fresh control and battery storage yard soil was 10.0126 and 10.0110, respectively, and after drying the weight was 9.9591 and 9.9228 , respectively. Therefore, the control soil moisture content was $0.53 \%$ and the battery storage yard soil moisture content was $0.88 \%$.

From the physical aspect, the soils are quite similar and this characteristic allows comparisons between them.

Concentration of metals in the soils is described in Table 2. It worth mentioning that Brazilian guidelines, reference quality values (RQV), prevention values (PV) and intervention values (IV), for the quality of the soil are presented in Table 2. RQV is the concentration of a certain substance that defines the natural quality of the soil, being determined based on statistical interpretation of physical- 
chemical analysis of samples of different types of soils. IV is the concentration of a given substance in soil or groundwater above which there are potential direct or indirect risks to human health, taking into account a standardized exposure scenario. Finally, PV is the concentration of the limit value of a substance in the soil, such that it is capable of sustaining its main functions. In Table 2 is possible to notice that the concentrations of most of the elements in the control and BSY soils are similar, except for lead.

The results of the avoidance behavior response test with the californian eartworm E. andrei are shown in Figure 1, with the fugacity of organisms exceeding $80 \%$, indicating restricted habitat functionality, as mentioned by by Loureiro et al. (2009).

The phytotoxicity data of elutriate and soil exposures are summarized in Figures 2 and 3. The soil collected in the BYS did not show toxicity to lettuce seeds when tested by direct exposure or by its elutriate. Thus, although the exposure to soil contaminated by battery tailings caused the escape of the earthworms, it did not affect germination or initial growth of Lactuca sativa under the conditions of this study.

\section{DISCUSSION}

Several studies (Loureiro et al., 2005; Sisinno et al., 2006) have used ecotoxicological analyzes with terrestrial organisms to show the sensitivity of these animals when exposed to soils contaminated by chemical substances. The study carried out by Gao et al. (2016) shows that Oligoqueta, Eisenia fetida, has a fugacity behavior when in contact with soils contaminated by metals, among them $\mathrm{Zn}$ and $\mathrm{Pb}$, being able to detect harmful substances and escape from these environments, thus demonstrating a good indicator for soil quality.

Electronic waste is composed of a variety of metals such as copper, aluminum, iron, zinc, nickel, lead, cadmium and mercury, and is often deposited with various types of plastic and ceramic materials (Damasceno et al., 2015). Waste of electric and electronic equipment are often disposed with organic and household garbage being destined to landfills or dumps, what results in a process of compostaging of organic matter along with electronic residues. Several studies have addressed the contamination of landfills by heavy metals from electronic waste such as batteries, demonstrating a growing concern about the potential negative environmental impact of this kind of waste (Li et al., 2009; KIDDEE et al., 2013).

The high concentration of lead in the evaluated soil is evident in Table 2, where BSY soil showed approximately 276 times more lead in its composition when compared to the control soil. Thus, it is possible to affirm the contamination by lead in these places where there is storage of lead-acid batteries.

Studies such as Machado et al. (2011) reported the concentrations of different metals in a controlled and inactive (for more than 30 years) dump. They observed that there is a tendency to decrease the $\mathrm{Zn}, \mathrm{Cu}, \mathrm{Pb}$ and $\mathrm{Cr}$ levels in the lower layers of the soil, even though they have concentrations above the reference values in the superficial layer. This reduction of

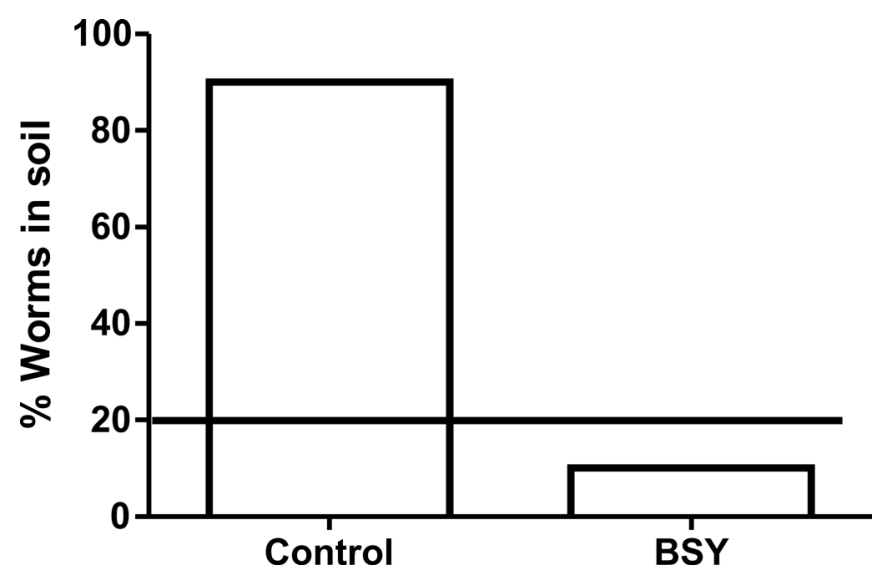

Figure 1. Results of avoidance behavior response test with earthworms exposed to soil contaminated by battery tailings, values in means $\pm \mathrm{SD}$. There was a statistical difference between the groups through the Fisher exact test.

Table 1. Physicochemical properties, granulometry and water retention capacity (WRC) of soil samples collected.

\begin{tabular}{lccccccccc}
\hline Soil & Type soil & pH & $\begin{array}{c}\text { Soil } \\
\text { moisture } \\
\mathbf{( \% )}\end{array}$ & $\begin{array}{c}\text { Organic } \\
\text { matter } \\
\mathbf{( \% )}\end{array}$ & $\begin{array}{c}\text { Gravel } \\
\mathbf{( \% )}\end{array}$ & $\begin{array}{c}\text { Sand } \\
\mathbf{( \% )}\end{array}$ & $\begin{array}{c}\text { Silt } \\
\mathbf{( \% )}\end{array}$ & $\begin{array}{c}\text { Clay } \\
\mathbf{( \% )}\end{array}$ & WRC* \\
\hline BSY & Spodosols & 9.73 & 0.53 & 4.69 & 4 & 78 & 7 & 11 & 48.3 \\
* Control & Spodosols & 6.02 & 0.88 & 4.35 & 0 & 85 & 7 & 8 & 50 \\
\hline
\end{tabular}

Table 2. Concentration of metallic elements $\left(\mathrm{mg} \mathrm{Kg}^{-1}\right)$ in soil samples and Brazilian guiding values (Conama, 2009).

\begin{tabular}{lccccccc}
\hline Soil & $\mathbf{C d}$ & $\mathbf{C u}$ & $\mathbf{P b}$ & $\mathbf{Z n}$ & $\mathbf{M n}$ & $\mathbf{F e}$ & As \\
\hline BSY & 294,08 & 33,99 & 10117,08 & 135,97 & 80,78 & 5274,60 & 2970,706 \\
Control & 558,0 & 31,64 & 36,70 & 102,45 & NM & NM & 2280,0 \\
RQV & 360 & 37 & 27 & 33 & - & - & NI \\
PV & 400 & 9 & 18 & 31 & - & - & NI \\
IV & 1300 & 60 & 72 & 300 & - & - & 15000 \\
\hline
\end{tabular}



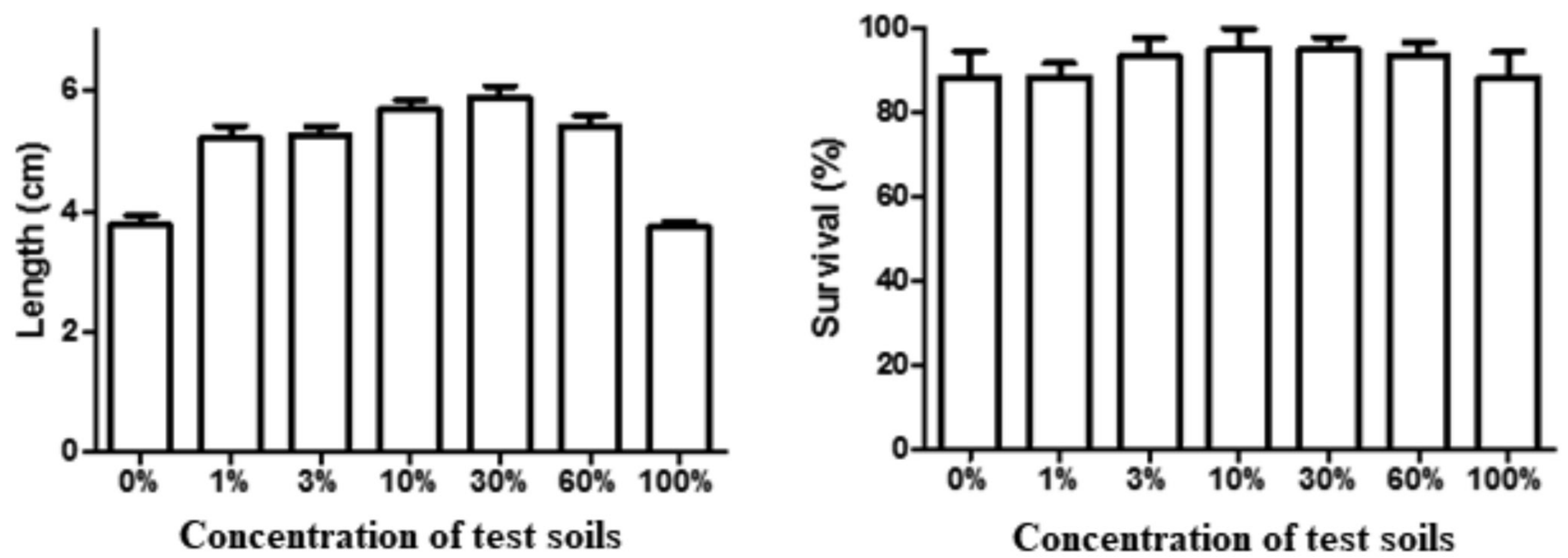

BSY soil

Figure 2. Survival and growth of lettuce seedlings exposed to the test soils from BSY, values in means \pm SD. No significant differences were found using ANOVA and post-hoc Dunnet with $5 \%$ significance.
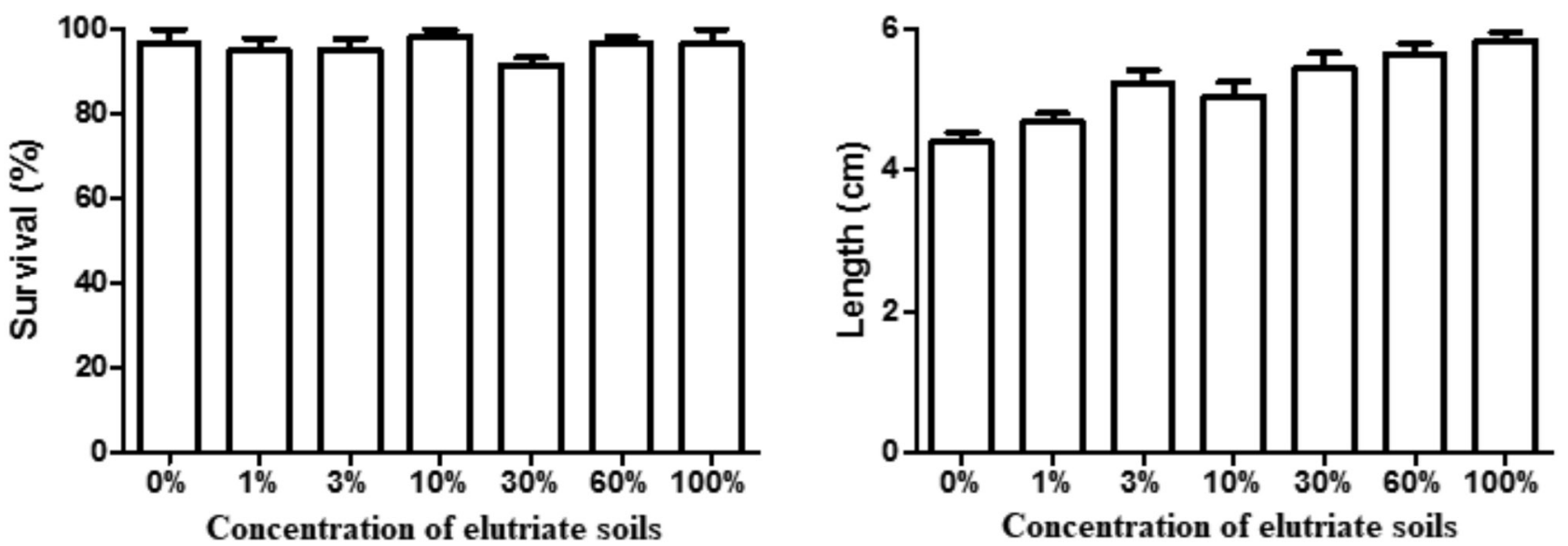

Elutriate from the BSY soil

Figure 3. Survival and growth of lettuce seedlings exposed to the elutriate from the test soils from BSY, values in means \pm SD. No significant differences were found using ANOVA and post-hoc Dunnet with 5\% significance.

metals can occur due to factors such as the retention of metal ions in the mass of garbage mixed with the soil, the adsorption of the metals in the soil particles and the precipitation of the metals in the stable forms (Cavallet et al., 2013).

The kinetics and the presence of heavy metals in the soil, mainly in old dumps, depends on the time of deposition of the residue, degradation and composition of the material, besides taking into account the climatic conditions and mineralogical compositions of the soil (Fontes \& Gomes, 2003). The $\mathrm{pH}$ values also have a strong influence on the adsorption and mobility of heavy metals (Wowk \& Melo, 2005), affecting the concentration in the soil solution. In acidic conditions, the adsorption is more significant in the control of the bioavailability of metals, whereas the solubility or precipitation and complexation reactions have a greater influence in neutral or alkaline conditions (Elliott et al., 1986).
Together with the acid component, part of the adverse effects investigated may be related to the presence of lead in high concentrations in the tested soil. This element present in the batteries causes toxic effects in plants and animals (Sharma \& Dubey, 2005).

Earthworms are annelids that have a beneficial effect on the functioning, maintenance and sustainability of the soil. Lavelle et al. (2006) highlighted some of the main functions of these organisms, as the movement of soil particles, resulting in the improvement of the structure and physical quality of the soil, and in the decomposition of organic matter (humus formation). These animals are considered bioindicators and good biomarkers of soil contamination, being exposed to contaminants through the epidermis and feeding. They are also used to monitor and verify the effectiveness of soil remediation procedures. In addition, these organisms are used in tests mainly for their characteristic to bioaccumulate and biomagnify contaminants (Castellanos \& Hernandez, 2007). 
The Figure 1 shows a high difference between the numbers of earthworms in the control soil and the BSY soil. This should occur mostly by the high concentration of lead, causing the worms to avoid being in the BSY soil and thus remain in the control soil.

Earthworms are a good model to investigate the ecotoxicity of contaminated soils, as explained in NIVA et al. (2016). The avoidance behavior response test with earthworms is widely used to assess soil quality, considering that soils in which the earthworms escape have limited functionality (Loureiro et al., 2009). Ecologically, this escape can mean local extinction of the species and consequently, loss of the ecological role exerted by earthworms in the soil.

In another approach, as described by Sharma et al. (2005), phytotoxicity assays was used to evaluate lead toxicity in different plant species in which the treatments tested influenced the activity of different enzymes with great metabolic importance for the process of photosynthesis. However, changes in the development of the plant exposed have an intrinsic relationship with many factors, such as the nature of the compounds, concentrations involved, sorption kinetics and product mobility (Jjemba, 2002).

In addition, we must take into account the sensitivity of each plant species to different pollutants. Being so, plants such as lettuce have been widely used as organisms for phytotoxicity testing due to their high sensitivity to metals (Eom et al., 2007).

Exposure to lead and its uptake during germination also varies from species to species due to differences in seed structure. This happens because metal exposure occurs only after the tegument rupture, where the toxicant is rapidly absorbed and accumulated in the meristematic regions of the roots and the hypocotyl, which may compromise plant development. Therefore, the tegument is considered a protection of the seed in the process of absorption of lead.

In our study the absence of phytotoxicity in the initial germination of $L$. sativa may be related to the intrinsic protection presented by this species, as was observed by Pereira et al. (2013), where the seeds of $L$. sativa presented a great tolerance to lead, probably due the protection and resistance of the tegument structure. Because to the resistance and high absorption of heavy metals, mainly lead, $L$. sativa contains a great phytoremediation potential, as demonstrated by Priebe et al. (2015). However, is important to notice that in a study made by Silva, Santos \& Guilherme (2015), root growth was inhibited by concentrations higher than $1 \mathrm{mM}$ of lead.

It is estimated that each year 330 thousand tons of lead are released into the atmosphere, $20 \%$ of which ends up being dispersed through the air. Air is considered the main route of dispersion of this metal, being able to be carried by winds and rains, accumulating in soil and water (Capellini et al., 2013). According to Braga \& Krusche (1999), the average of winds speed in the city of Rio Grande is approximately $10.2 \mathrm{~km} / \mathrm{h}$, which is an average of the sum of all directions of the winds, and the average of the highest velocity peak was
$20.6 \mathrm{~km} / \mathrm{h}$ for southbound winds. Thus, it is possible that the high concentration of lead in soil (Garcia et al., 2010) and atmospheric air (Vanz et al., 2003) in this city is directly related to the storage sites of lead-acid batteries, because after a certain time these lead particles can be carried by the wind to other parts of the city, distributing itself along the soil of the region.

\section{CONCLUSION}

In the present study, both biological models were useful to predict damages due to exposure to battery rejects in the soil and are configured as tools to be incorporated in the evaluation of soil quality in cases of lead contamination. Although these results are preliminary, these are important data regarding the resistance of $L$. sativa, under the conditions tested on soil contaminated by battery tailings. Other parameters and experimental conditions should be used to evaluate the existence of sublethal effects on growth, development and bioaccumulation in plants, including L. sativa, using soil contaminated by battery rejects.

\section{REFERENCES}

ABNT. 2014. Qualidade do solo. Determinação dos efeitos de poluentes na flora terrestre. Parte 2: Efeitos do solo contaminado na emergencia e no crescimento inicial de vegetais superiores. NBR 11269.

ABNT. 2011. Qualidade do Solo. Ensaio de fuga para avaliar a qualidade de solos e efeitos de substâncias químicas no comportamento Parte 1: Ensaio com minhocas (Eisenia fetida e Eisenia andrei) NBR ISO 17512-1.

ABNT. 2014. Ecotoxicologia terrestre. Toxicidade aguda - Método de ensaio com minhocas (Lumbricidae) NBR 15537.

AZEVEDO, F.A., CHASIN, A.A.M. 2003. Metais gerenciamento da toxicidade. Editora Atheneu, São Paulo, 554 p.

BRAGA, M. F. S., KRUSCHE, N. 1998. Análise da frequência das velocidades do vento em Rio Grande, RS. X congresso Brasileiro de Meteorologia, Anais, Brasília-DF.

CAPELLINI, V. L. M. F., RODRIGUES, O. M. P. R., MELCHIORI, L. E., VALLE, T. G. M. 2013. Crianças contaminadas por chumbo: Estudo comparativo sobre desempenho escolar. Estud. Aval. Educ., 19(39): 155-180. http://dx.doi.org/10.1590/21753539/2014/0183789

CASTELlANOS, L. R., HERNANDEZ, J. C. S. 2007. Earthworm biomarkers of pesticide contamination: Current status and perspectives. J. Pestic. Sci., 32: 360-371. https://dx.doi. org/10.1584/jpestics.R07-14

CAVAlLET, L. E., CARVALHO, S. G., NETO, P.F. 2013. Metais pesados no rejeito e na água em área de descarte de resíduos sólidos urbanos. Amb. água, 8(3): 229-238. https://dx.doi. org/10.4136/ambi-agua.1155

CETESB (Companhia Ambiental do Estado de São Paulo). 1999. Amostragem do solo 6300, 1 - 44.

CHEN, C. M., LIU, M. C. 2006. Ecological risk assessment on a cadmium contaminated soil landfill - A preliminary evaluation based on toxicity tests on local species and site-specific information. Sci. Total Env. 359(1): 120-129. https://dx.doi. org/10.1016/j.scitotenv.2005.04.041

CHAO, G., JINGBO, X., JI, L., ZHENGTAO, L. 2016. Biological 
Responses in the Earthworm Eisenia fetida Exposed to Soils near a Typical Lead Acid Battery Plant. Soil Sediment. Contam., 25(5): 573-585. http://dx.doi.org/10.1080/15320383.2016.11846 19

CHEN, L., XU, Z., LIU, M. HUANG,Y., FAN, R., SU, Y., PENG, X. 2012. Lead exposure assessment from study near a lead-acid battery factory in China. Sci. Total Env., 429: 191-198. https:// dx.doi.org/10.1016/j.scitotenv.2012.04.015

DAMASCENO, O. I. C., REIS, C., REIS, E. L., BELLATO, C. R., FIDÊNCIO, P. H. 2015. Assessment of bioavailability of heavy metals after vermicomposting in the presence of electronic waste. Rev. Bras. Ciên. Solo, 39(6). http://dx.doi.org/10.1590/0 1000683 rbcs 20150060

DA SILVA JÚNIOR, F. M. R., GARCIA, E. M., MUCCILlOBAISCH, A. L. 2014. Acute toxicity of soil samples under the atmospheric influence of an industrial complex using Swiss mice. Ecotox. Environ. Contam., 9(1): 29-31. https://dx.doi. org/10.5132/eec.2014.01.004

DA SILVA JÚNIOR, F. M. R., GARCIA, E. M., MUCCILLOBAISCH, A. L., MIRLEAN, N., BAISCH, A. L. M. 2013. Assessment of a Soil with Moderate Level of Contamination using Lettuce Seed Assay and Terrestrial Isopods Assimilation Assay. Soil Wat. Res., 8(2): 56-62.

Ellioty, H. A., LiBERATI, M. R., HUANG, C. P. 1986. Competitive adsorption of heavy metals by soils. J. Environ. Qual., 15(3): 214-217. https://dx.doi.org/10.2134/ jeq1986.00472425001500030002x

EOM, I. C., RAST, C., VEBER, A. M., VASSEUR, P. 2007. Ecotoxicity of a polycyclic aromatic hydrocarbon (PAH)contaminated soil. Ecotox. Environ. Saf., 67(2): 190-205. https:// dx.doi.org/10.1016/j.ecoenv.2006.12.020

FONTES, M. P. F., GOMES, P. C. 2003. Simultaneous competitive adsorption of heavy metals by the minerals matrix of tropical soils. Appl. Geochem., 18: 795-804. https://dx.doi.org/10.1016/ S0883-2927(02)00188-9

FRAGOMENI, L. P. D. M., ROISENBERG, A. MIRLEAN, N. 2010. Poluição por mercúrio em aterros urbanos do período colonial no extremo sul do Brasil. Quím., 33(8) http://dx.doi. org/10.1590/S0100-40422010000800002

GAO, M., LV, M., HAN, M., SONG, W., WANG, D. 2016. Avoidance behavior of Eisenia fetida in oxytetracycline - and heavy metal - contaminated soils. Environ. Tox. Pharmacol., 46: 119-123. https://dx.doi.org/10.1016/j.etap.2016.09.011

GARCIA, F. A. D. P., MIRLEAN, N., BAISCH, P. R. M. 2010. Marcadores metálicos como avaliação do impacto crônico de emissões petroquímicas em zona urbana. Quím. Nova, 33(3): 716720. https://dx.doi.org/10.1590/S0100-40422010000300040

IRWIN, R.J., VAN MOUWERIK, M. A. R. K., STEVENS, L., SEESE, M. D., BASHAM, W. 1997. Environmental Contaminants Encyclopedia: Lead Entry. National park service water, $117 \mathrm{p}$.

JJMBA, P. K. 2002. The potential impact of veterinary and human therapeutic agents in manure and biosolids on plants grown on arable land: A review. Agri, Ecosys. Env., 93: 267-278. https:// dx.doi.org/10.1016/S0167-8809(01)00350-4

KIDDEE, P., NAIDUA, R., WONG, M. H. 2013. Metals and polybrominated diphenyl ethers leaching from eletronic waste in simulated landfills. J. Haz. Mat., 252(253): 243-249. https:// dx.doi.org/10.1016/j.jhazmat.2013.03.015

LAVELLE, P., DECAËNS, T., AUBERT, M., BAROT, S., BLOUIN, M., BUREAU, F., MARGERIE, P., MORA, P., ROSSI, J. P. 2006. Soil invertebrates and ecosystem services. Eur. J. Soil. Biol., 42: 3-15. https://dx.doi.org/10.1016/j.ejsobi.2006.10.002

LIU, G., YU, Y., HOU, J., XUE, X., LIU, Y., LIU, Z. 2014.
An ecological risk assessment of heavy metal pollution of the agricultural ecosystem near a lead-acid battery factory. Ecol. Indic., 47: 210-218. https://dx.doi.org/10.1016/j. ecolind.2014.04.040

LI, Y., RICHARDSON, J. B., BRICK, R. M., NIU, X., YANG, H., LI, L., JIMENEZ, A. 2009. Leaching of heavy metals from e-waste in simulated landfill columns. Waste Manage., 29: 2147 50. https://dx.doi.org/10.1016/j.wasman.2009.02.005

LOUREIRO, S., AMORIM, M. J. B., CAMPOS, B., RODRIGUES, S. M. G., SOARES, A. M. V. M. 2009. Assessing joint toxicity of chemicals in Enchytraeus albidus (Enchytraeidae) and Porcellionides pruinosus (isopoda) using avoidance behavior as an endpoint. Environ. Pollut., 157: 625-636. https://dx.doi. org/10.1016/j.envpol.2008.08.010

LOUREIRO, S., SOARES, A. M. V. M., NOGUEIRA, A. J. A. 2005. Terrestrial avoidance behaviour tests as screening tool to assess soil contamination. Environ. Pollut., 138: 121-131. https:// dx.doi.org/10.1016/j.envpol.2005.02.013

MACHADO, M. E., MENEZES, J. C. S. S., COSTA, J. F. C. L., SCHNEIDER, I. A. H. 2011. Análise e avaliação da distribuição de metais pesados em um antigo aterro de resíduos sólidos urbanos "Aterro Invernadinha". Evidência, Joaçaba, 1(2): 69-82.

MAO, J., LU, Z., YANG, Z. 2006. The Eco-efficiency of lead in China's lead-acid battery system. J Ind Ecol, 10 (1-2): 185-197. http://dx.doi.org/10.1162/108819806775545457

NIVA, C. C., NIEMEYER, J. C. DA SILVA JÚNIOR, F. M. R., NUNES, M. E. T., DE SOUZA, D. L, ARAGÃO, C. W., SAUTTER, K. D., ESPINDOLA, E. G., SOUZA, J. P., RÖMBKE, J. 2016. Soil ecotoxicology in Brazil is taking its course. Environ. Sci. Pollut. Res., 23(11): 11363-78. http:// dx.doi.org/10.1007/s11356-016-6597-1

OMOURI, Z., HAWARI, J., FOURNIER, M., ROBIDOUX, P., Y. 2018. Bioavailability and chronic toxicity of bismuth citrate to earthworm Eisenia andrei exposed to natural sandy soil. Ecotox. Environ. Safe, 147: 1-8. https://dx.doi.org/10.1016/j. ecoenv.2017.08.018.

ONIANWA, P. C., FAKAYODE, S. O. 2000. Lead contamination of topsoil and vegetation in the vicinity of a battery factory in Nigeria. Environ. Geochem. Hlth, 22(3): 211-218. https://dx.doi. org/10.1023/A:1026539531757

PEREIRA, M. P., PEREIRA, F. J., DE ALMEIDA RODRIGUES, L. C., BARBOSA, S., DE CASTRO, E. M. 2013. Fitotoxicidade do chumbo na germinação e crescimento inicial de alface em função da anatomia radicular e ciclo celular. Rev. Agro@mbiente, 7(1): 36-43. http://dx.doi.org/10.18227/1982-8470ragro.v7i1.895

PRIEBE, T. F., FAISTEL, K. T., FERREIRA, K. C. S., VASCONCELOS, L., BORGES, F. 2015. Verificação da capacidade de absorção de metais pesados pelo vegetal Lactuca sativa (alface), através de fitorremediação. Anais Expoulbra, Canoas, RS, Brasil.

QUITERIO, S. L., MOREIRA, F. R., SILVA, C. R. S. D., ARBILLA, G., ARAÚJO, U. C., MATTOS, R. C. O. C. 2006. Avaliação da poluição ambiental causada por particulado de chumbo emitido por uma reformadora de baterias na cidade do Rio de Janeiro, Brasil. Cad. Saúde Pública, 22(9): 1817-1823. http://dx.doi. org/10.1590/S0102-311X2006000900012

RAUCH, J. N., PACYNA, J. M. 2009. Earth's global Ag, Al, Cr, $\mathrm{Cu}, \mathrm{Fe}, \mathrm{Ni}, \mathrm{Pb}$, and $\mathrm{Zn}$ cycles. Global Biogeochem. Cy., 23(2). https://dx.doi.org/10.1029/2008GB003376

ROBERTSON, J., THOMAS, C. J., CADDY, B., LEWIS, A. J. M. 1984. Particle size analysis of soils - A comparison of dry and wet sieving techniques. Forensic Sci. Int., 24: 209-217. https:// doi.org/10.1016/0379-0738(84)90186-5

SANTOS, R. A., SALES, M. L., CAMPOLINO, M. L. 2017. 
Sementes de Lactuca sativa (alface) como bioindicador da toxicidade da água dos córregos urbanos J.K e Interlagos, região sudeste de Sete Lagoasminas Gerais. Rev. Bras. Ciên Vida, 5(1).

SHARMA, P., DUBEY, R. S. 2005. Lead toxicity in plants. Journal of Plant Physiology, 17: 35-52 http://dx.doi.org/10.1590/S167704202005000100004

SILVA, E., SANTOS, P. S., GUILHERME, M. F. S. 2015. Lead in plants: A brief review of its efects, mechanisms toxicological and remediation. Agrarian Acad. 2(03): 1-20.

SISINNO, C. L. S., BULUS, M. R. M., RIZZO, A. C., MOREIRA, J. C. 2006. Ensaio de comportamento com minhocas (Eisenia fetida) para avaliação de áreas contaminadas: Resultados preliminares para a contaminação por hidrocarbonetos. J. Braz. Soc. Ecotox., 1(2): 1-4.

VAN DER KUJIP, T. J. HUANG, L. CHERRY, C. R. 2013. Health hazards ofChina's lead-acid battery industry: a review of its market drivers, production processes, and health impacts. Environ. Hlth, 12(1): 61. https://dx.doi.org/10.1186/1476-069X-12-61

VANZ, A., MIRLEAN, N., BAISCH, P. 2003. Avaliação de poluição do ar por chumbo particulado: uma abordagem geoquímica. Quím. nova, 26(1): 25-29. http://dx.doi.org/10.1590/ S0100-40422003000100006

WIJAYAWARDENA, M. A. A., MEGHARAJ, M., NAIDU, R., STOJANOVSKI, E. 2017. Chronic and reproductive toxicity of cadmium, zinc, and lead in binary and tertiary mixtures to the earthworm (Eisenia fetida). J Soils Sediments, 1-8. https:// dx.doi.org/10.1007/s11368-017-1877-z

WOWK, G. I. T. H., MELO, V. F. 2005. Evaluation of the lead level, in low land soil, originated from a recycling of batteries. Rev. Bras. Eng. Agri. Amb., 9(4). http://dx.doi.org/10.1590/S141543662005000400027 